\title{
Magnesium Fluoride Forms Unique Protein Corona for Efficient Delivery of Doxorubicin into Breast Cancer Cells
}

\author{
Hamed Al-Busaidi ${ }^{1}$, Md. Emranul Karim ${ }^{1}{ }^{\circledR}$, Syafiq Asnawi Zainal Abidin ${ }^{1}{ }^{\mathbb{D}}$, Kyi Kyi Tha ${ }^{1,2}$ \\ and Ezharul Hoque Chowdhury ${ }^{1,2, *}$ \\ 1 Jeffrey Cheah School of Medicine and Health Sciences, Monash University Malaysia, Jalan Lagoon Selatan, \\ Bandar Sunway, Subang Jaya 47500, Malaysia; halb0005@student.monash.edu (H.A.-B.); \\ karim604306@gmail.com (M.E.K.); syafiqnawi@gmail.com (S.A.Z.A.); tha.kyi.kyi@monash.edu (K.K.T.) \\ 2 Health \& Wellbeing Cluster, Global Asia in the 21st Century (GA21) Platform, Monash University Malaysia, \\ Jalan Lagoon Selatan, Bandar Sunway, Subang Jaya 47500, Malaysia \\ * Correspondence: md.ezharul.hoque@monash.edu; Tel.: +603-5514-4978; Fax: +603-5514-6323
}

Received: 28 January 2019; Accepted: 14 February 2019; Published: 22 February 2019

\begin{abstract}
Background: The efficacy of chemotherapy is undermined by adverse side effects and chemoresistance of target tissues. Developing a drug delivery system can reduce off-target side effects and increase the efficacy of drugs by increasing their accumulation in target tissues. Inorganic salts have several advantages over other drug delivery vectors in that they are non-carcinogenic and less immunogenic than viral vectors and have a higher loading capacity and better controlled release than lipid and polymer vectors. Methods: $\mathrm{MgF}_{2}$ crystals were fabricated by mixing $20 \mathrm{mM}$ $\mathrm{MgCl}_{2}$ and $10 \mathrm{mM} \mathrm{NaF}$ and incubating for $30 \mathrm{~min}$ at $37{ }^{\circ} \mathrm{C}$. The crystals were characterized by absorbance, dynamic light scattering, microscopic observance, $\mathrm{pH}$ sensitivity test, SEM, EDX and FTIR. The binding efficacy to doxorubicin was assessed by measuring fluorescence intensity. $\mathrm{pH}$-dependent doxorubicin release profile was used to assess the controlled release capability of the particle-drug complex. Cellular uptake was assessed by fluorescence microscopy. Cytotoxicity of the particles and the drug-particle complex were assessed using MTT assay to measure cell viability of MCF-7 cells. Results and Discussion: Particle size on average was estimated to be $<200 \mathrm{~nm}$. The crystals were cubic in shape. The particles were $\mathrm{pH}$-sensitive and capable of releasing doxorubicin in increasing acidic conditions. $\mathrm{MgF}_{2}$ nanocrystals were safe in lower concentrations, and when bound to doxorubicin, enhanced its uptake. The protein corona formed around $\mathrm{MgF}_{2}$ nanoparticles lacks typical opsonins but contains some dysopsonins. Conclusion: A drug delivery vector in the form of $\mathrm{MgF}_{2}$ nanocrystals has been developed to transport doxorubicin into breast cancer cells. It is $\mathrm{pH}$-sensitive (allowing for controlled release), size-modifiable, simple and cheap to produce.
\end{abstract}

Keywords: $\mathrm{MgF}_{2}$; nanoparticle; drug delivery; cellular uptake; cytotoxicity; opsonin; dysopsonin; $\mathrm{pH}$-sensitive; drug release; protein corona

\section{Introduction}

Breast cancer treatment constitutes a large proportion of worldwide health expenditure. In the US, it costs an average of $\$ 537$ per person per month [1]. In addition, chemotherapy-related adverse effects cost \$1271 per person per year and ambulatory encounters $\$ 17,617$ per person per year [2]. The cost of care for breast cancer could be significantly reduced by employing a drug delivery system to reduce the administered dose of the drug and off-target side effects.

Using nanoparticles as drug delivery agents has gained increased interest to researchers due to several advantages, such as targeting cancer cells, reducing off-target effects, reducing systemic 
clearance of the drug, increasing drug uptake into the cell, capacity to deliver a wide range of therapeutics including siRNA and DNA, and combining drug delivery with other modes of treatment e.g., hyperthermia [3] and imaging [4].

However, there are some issues related to the use of nanoparticles. These include accumulation within liver, spleen, kidney and reticuloendothelial system, and difficulties with targeting cancer cells, since nanoparticles rely on the availability of adequate circulation (to accumulate in cancer tissue) and lymphatic drainage (to prevent a rise in intratumoural pressure which would hamper the movement of nanoparticles). To address these problems, different types of nanoparticles have been developed and new ones still are being developed.

Inorganic salts such as Group 2 metal fluorides, carbonates, sulfates and sulfites have plenty of advantages over other drug delivery systems in that they are non-carcinogenic and less immunogenic than viral vectors, and have a higher loading capacity and better controlled release than lipid and polymer vectors. They are simple and thereby cheaper to produce, size-modifiable and can be conjugated with targeting moieties. In particular, magnesium is higher up the Group 2 metals table, making it less reactive (hence more stable) than calcium, strontium and barium particles. The ubiquity of magnesium in the human body [5] suggests that it would have less toxicity risks, by comparison to iron, gold and silver nanoparticles. Water-insoluble magnesium salt particles would thus present an excellent candidate for research on drug delivery.

Doxorubicin is a commonly studied drug in breast cancer research. It is an anthracycline drug used to treat breast cancer. Doxorubicin's mechanism of action involves intercalating DNA directly and inhibiting its uncoiling; inhibition of topoisomerase enzymes and generating free radicals. These actions damage DNA, inhibit DNA replication and ultimately lead to cell death (by apoptosis). Doxorubicin's use is largely limited by its cardiotoxicity [6,7]. Strategies used to address the issue of doxorubicin toxicity have included the fabrication of nanoparticle delivery systems, the development of doxorubicin analogs; the use of low dose, prolonged, continuous infusion regimens and combining doxorubicin treatment with dexrazoxane, a cardioprotective drug [8].

Nanoparticle formulations employed to deliver doxorubicin include liposomes, polymers and inorganic particles. Liposomes are rapidly cleared by the reticuloendothelial system (within a few hours) and thus have a short half-life. To fix this problem, liposomes were conjugated with polymers such as polyethylene glycol (PEG). PEGylated liposomal doxorubicin (Doxil ${ }^{\circledR}$ ) has been approved by the food and drug administration (FDA) for treating ovarian cancer. Despite increasing the half-life of liposomal doxorubicin, PEGylation increases the risk of hand-foot syndrome, also known as palmar-plantar erythrodysesthesia [8]. Superparamagnetic iron oxide (SPION) nanoparticles can add imaging (as contrast agents for MRI) and hyperthermia functions to doxorubicin delivery. Despite this promising prospect, more studies will be needed to assess their cytotoxicity [9].

Here we report on the first use of magnesium fluoride as a drug delivery agent for doxorubicin in cancer treatment, its manufacture, binding and release under $\mathrm{pH}$ change, cellular uptake and cytotoxicity. Magnesium fluoride nanoparticles were successfully produced and bound to doxorubicin. Fluorescent microscopic images showed successful internalisation of the drug-bound nanoparticles by MCF-7 cells. MTT analysis showed an increased toxicity when doxorubicin was bound to $\mathrm{MgF}_{2}$ nanoparticles. Protein corona was analysed by LC/MS and contained a distinct lack of typical opsonins such as immunoglobulins and complement proteins, crucial for clearance by macrophages.

\section{Materials and Methods}

\subsection{Materials Used}

$\mathrm{MgCl}_{2}, \mathrm{NaF}, \mathrm{NaHCO}_{3}, 8.621 \mathrm{mM}$ doxorubicin-hydrochloride (Dox) D1515, Foetal bovine serum (FBS), Trypsin-ethylenediaminetetraacetic acid (EDTA), $\mathrm{Na}_{2} \mathrm{HPO}_{4}, \mathrm{~K}_{2} \mathrm{HPO}_{4}$, Thiazolyl blue tetrazolium bromide (MTT), dimethyl sulfoxide (DMSO), TrypLE, penicillin streptomycin, HEPES and liquid Dulbecco's modified eagle medium (DMEM) were bought from Sigma Aldrich (St. Louis, MO, 
USA). DMEM was bought from Gibco by Life Technology (Thermo Fischer Scientific, Waltham, MA, USA). $\mathrm{NaCl}, \mathrm{KCl}$ and $\mathrm{HCl}$ were bought from Fischer Scientific (Loughborough, UK). Milli-Q water purification from Millipore was used.

\subsection{Fabrication of Nanocrystals}

$\mathrm{MgCl}_{2}$ was fixed at $20 \mu \mathrm{L}$ of $1 \mathrm{M}$ and mixed with increasing concentrations of $\mathrm{NaF} ; 10,20,30,40$, $50 \mu \mathrm{L}$ of $1 \mathrm{M}$. The solution was incubated at $37^{\circ} \mathrm{C}$ for $30 \mathrm{~min}$, after which $10 \%$ FBS-supplemented DMEM was added to make a total of $1 \mathrm{~mL}$. The $\mathrm{pH}$ was calibrated within the range of 7.4 to 7.55.

Formation of nanoparticles was estimated using a Jasco UV-VIS spectrophotometer (Ocklahoma city, OK, USA) to measure absorbance values at $320 \mathrm{~nm}$ wavelength. Samples were measured in triplicates and an average value was calculated.

The effect of incubation time on the formation of nanocrystals was determined using the same procedure, but incubating for $60 \mathrm{~min}$ for comparison.

\subsection{Dynamic Light Scattering (DLS)}

Particles were prepared as mentioned in Section 2.2.

Dynamic light scattering was performed to estimate particle sizes. Measurements were made using Malvern nano zeta sizer (Worcestershire, UK) and accompanying software. Samples were measured in duplicates and an average value was calculated.

\subsection{Microscopic Observation of Particles}

Particles were prepared as mentioned in a previous section. The particles were visualised in brightfield 10× magnification. The microscope used was Olympus Fluorescence Microscope IX81 and CellSens Dimension software (Tokyo, Japan).

\subsection{Fourier Transform Infrared Spectroscopy (FTIR)}

$2 \mathrm{~mL}$ of $1 \mathrm{M} \mathrm{MgCl}_{2}$ was added to $1 \mathrm{~mL}$ of $1 \mathrm{M} \mathrm{NaF}$. The samples were then incubated at $37^{\circ} \mathrm{C}$ for $30 \mathrm{~min} .97 \mathrm{~mL}$ of $10 \%$ FBS-supplemented DMEM was added to make a total of $100 \mathrm{~mL}$, which was then centrifuged at $3000 \mathrm{rpm}, 4{ }^{\circ} \mathrm{C}$ for $45 \mathrm{~min}$. The supernatant was then discarded, and the precipitate was freeze-dried using Labconco freeze dryer (Kansas city, MO, USA).

Varian FTIR (Santa Clara, CA, USA) and Varian Resolution Pro 640 software were used to check the spectra of the $\mathrm{MgF}_{2}$ particles.

\subsection{Field Emission Scanning Electron Microscope (FE-SEM) and Energy Dispersive X-Ray Spectroscopy (EDX)}

$\mathrm{MgF}_{2}$ particles were prepared by adding $20 \mu \mathrm{L}$ of $1 \mathrm{M} \mathrm{MgCl}_{2}$ to $10 \mu \mathrm{L}$ of $1 \mathrm{M} \mathrm{NaF}$. The sample was incubated at $37^{\circ} \mathrm{C}$ for $30 \mathrm{~min} .3 \mu \mathrm{L}$ of the sample was then left to dry for $15 \mathrm{~h}$ on a glass slip. The dried sample was subjected to platinum sputtering for $45 \mathrm{~s}$ at a current of $30 \mathrm{~mA}$, and a tooling factor of 2.3. The particles were visualised at $10 \mathrm{kV}$ (for EDX) and $5 \mathrm{kV}$ (for SEM). The device used was Hitachi/SU8010 (Tokyo, Japan).

\section{7. pH Sensitivity of the Nanoparticles}

$20 \mu \mathrm{L}$ of $1 \mathrm{M} \mathrm{MgCl}_{2}$ was added to $10 \mu \mathrm{L}$ of $1 \mathrm{M} \mathrm{NaF}$ and the sample was incubated at $37^{\circ} \mathrm{C}$ for $30 \mathrm{~min}$. DMEM with 10\% FBS media was added to the sample, adjusted to $\mathrm{pH}$ values in the range: $7.5,7.0,6.5,6.0,5.5$. The samples were then measured for absorbance using Jasco UV-VIS spectrophotometer. The samples were prepared in triplicates and a mean value was calculated.

\subsection{Binding Efficiency of Particles to Doxorubicin}

To estimate the drug binding affinity of $\mathrm{MgF}_{2}$ nanoparticles, doxorubicin-bound nanoparticles were generated by adding $20 \mu \mathrm{L}$ of $1 \mathrm{M}$ of $\mathrm{MgCl}_{2}, 10 \mu \mathrm{L}$ of $1 \mathrm{M} \mathrm{NaF}$ and doxorubicin in varying 
concentrations of $5,10,15$ and $20 \mu \mathrm{M}$. The samples were then incubated at $37^{\circ} \mathrm{C}$ for $30 \mathrm{~min}$ and centrifuged at $6000 \mathrm{rpm}, 4^{\circ} \mathrm{C}$ for $20 \mathrm{~min}$. The supernatant was then discarded and the precipitate resuspended in $100 \mu \mathrm{L}$ of EDTA $(5 \mathrm{mM})$ in PBS. The final samples were placed in 96 well plates.

PerkinElmer microplate reader (Waltham, MA, USA) was used to measure their fluorescence intensity, and a standard curve of doxorubicin concentration against fluorescence intensity was plotted, shown in Figure 1. The fraction of doxorubicin present in the final nanoparticle suspension divided by the concentration originally used to form the nanoparticle suspension gives us the binding affinity.

All samples were prepared in triplicates and a mean result was taken.

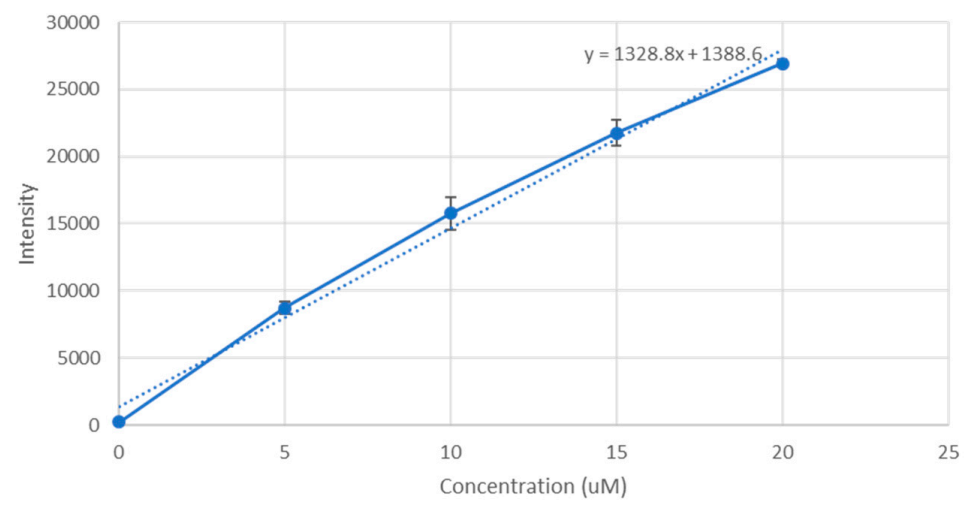

Figure 1. A standard graph of fluorescence intensity vs concentration of doxorubicin. Doxorubicin was prepared in concentrations of 0,5,10,15 and $20 \mu \mathrm{M}$ in PBS. The samples were placed in 96 well plates and measured for fluorescence intensity using PerkinElmer microplate reader. The excitation wavelength was set to $495 \mathrm{~nm}$ and emission wavelength was set to $535 \mathrm{~nm}$. The results were plotted into a scatter graph. Regression analysis of the results was used to construct a straight line graph with the formula $y=m x+c$, where ' $y$ ' is the fluorescence intensity measure and ' $x$ ' is the concentration of doxorubicin. $R^{2}=0.990441$.

\section{9. $p H$ Release Profile of Doxorubicin}

$20 \mu \mathrm{L}$ of $1 \mathrm{M} \mathrm{MgCl}_{2}, 10 \mu \mathrm{L}$ of $1 \mathrm{M} \mathrm{NaF}, 50 \mu \mathrm{L}$ of $100 \mu \mathrm{M}$ doxorubicin were added together. The sample was incubated at $37^{\circ} \mathrm{C}$ for $30 \mathrm{~min}$. The samples were then added to $\mathrm{pH}$-adjusted media in the ranges of: $7.5,7.0,6.5,6.0,5.5,5.0$. Next, the samples were centrifuged at $6000 \mathrm{rpm}$, and $4{ }^{\circ} \mathrm{C}$ for $20 \mathrm{~min}$. The supernatant was then discarded leaving behind $30 \mu \mathrm{L}$ of precipitate, which was resuspended in $170 \mu \mathrm{L}$ of $5 \mathrm{mM}$ EDTA in PBS. A control sample was prepared by $30 \mu \mathrm{L}$ of $10 \%$ FBS-supplemented DMEM media at $7.5 \mathrm{pH}$ dissolved in $170 \mu \mathrm{L}$ of EDTA (in order to subtract DMEM's own fluorescence intensity from the samples' values). The samples were placed in a 96 well microplate, and fluorescence intensity was then measured using PerkinElmer microplate reader. Each sample was prepared as a triplicate and a mean value calculated.

\subsection{Cell Culture and Seeding}

MCF-7 cells were incubated in a $25 \mathrm{~cm}^{3}$ flask in liquid DMEM media supplemented with $1 \%$ HEPES buffer media, $1 \%$ streptomycin and $10 \%$ FBS. The flask was incubated in $37^{\circ} \mathrm{C}$ and $5 \% \mathrm{CO}_{2}$. MCF-7 cells in DMEM were seeded into 24 well plates (Greiner, Germany). 50,000 cells were seeded per well. Estimations of cell counts were made using a Hirschmann counting chamber (haemocytometer). The wells were incubated in $37^{\circ} \mathrm{C}$ and $5 \% \mathrm{CO}_{2}$ for $24 \mathrm{~h}$.

\subsection{Cellular Uptake of Doxorubicin-Bound Nanoparticles}

Cells were seeded as mentioned before.

The cells were then treated with $\mathrm{MgF}_{2}$ - bound doxorubicin complexes, prepared by adding $20 \mu \mathrm{L}$ of $1 \mathrm{M} \mathrm{MgCl}_{2}, 10 \mu \mathrm{L}$ of $1 \mathrm{M} \mathrm{NaF}$ and $10 \mu \mathrm{M}$ doxorubicin; incubation at $37^{\circ} \mathrm{C}$ for $30 \mathrm{~min}$; and adding $10 \%$ FBS-supplemented DMEM media to make a $1 \mathrm{~mL}$ suspension. 
The control was $10 \mu \mathrm{M}$ doxorubicin in $1 \mathrm{~mL}$ of 10\% FBS-supplemented DMEM media. Uptake was determined by fluorescence images taken after $2 \mathrm{~h}$. Media was removed from the wells, and the wells were rinsed with $100 \mu \mathrm{L}$ of $5 \mathrm{mM}$ EDTA followed by $100 \mu \mathrm{L}$ PBS twice. Then $100 \mu \mathrm{L}$ PBS was added to the wells before observation. The microscope used was Olympus Fluorescence Microscope IX81 and CellSens Dimension software.

\subsection{Cytotoxicity of $\mathrm{MgF}_{2}$ Particles}

Cells were cultured and seeded as mentioned above. Nanoparticles were fabricated by adding $20 \mu \mathrm{L}$ of $1 \mathrm{M} \mathrm{MgCl}_{2}$ and a range of concentrations of NaF: 10, 20,30, 40, $50 \mathrm{uL}$ of $1 \mathrm{M} \mathrm{NaF}$, and incubated at $37^{\circ} \mathrm{C}$ for $30 \mathrm{~min}$. The nanoparticle samples were then centrifuged at $13,000 \mathrm{rpm}$ and $20^{\circ} \mathrm{C}$ for $10 \mathrm{~min}$. The supernatant was discarded leaving behind $10 \mu \mathrm{L}$ of precipitate. The precipitate was then resuspended in $990 \mu \mathrm{L}$ of DMEM with $10 \%$ FBS. The cells were treated with these samples then incubated for $48 \mathrm{~h}$. Cell viability was then measured using an MTT assay (described below). DMEM media was used as a control. Samples were measured as triplicates and a mean value was calculated.

\subsection{Measuring Toxicity of Doxorubicin-Bound $\mathrm{MgF}_{2}$ Particles by MTT Assay}

Cells were cultured and seeded as mentioned previously, then treated with nanoparticle- bound doxorubicin. Particles were formed using $10 \mu \mathrm{L}$ of $1 \mathrm{M} \mathrm{NaF}$ added to $20 \mu \mathrm{L}$ of $1 \mathrm{M} \mathrm{MgCl}_{2}$. Dox drugs of 100, 200, 300, 400 and $500 \mathrm{nM}$ concentrations were used. The treated cells were incubated for $48 \mathrm{~h}$. Cell viability was then measured using an MTT assay, as described below. Plain DMEM media, as well as unbound Dox of concentrations 100, 200, 300, 400, $500 \mathrm{nM}$ were used as controls. All samples were measured as triplicates and a mean value was calculated. $50 \mu \mathrm{L}$ of MTT solution was added to each well. The wells were then incubated in $5 \% \mathrm{CO}_{2}$ and $37^{\circ} \mathrm{C}$ for $4 \mathrm{~h}$. After incubation, formazan crystals were formed in the wells. The solutions in the wells were discarded and $300 \mu \mathrm{L}$ DMSO was used to dissolve the formazan crystals (over $5 \mathrm{~min}$ ). The dissolved formazan solutions were then measured for absorbance, using a spectrophotometer (Bio-Rad Microplate Reader, Hercules, CA, USA) at wavelength of $595 \mathrm{~nm}$ and reference wavelength $630 \mathrm{~nm}$.

The samples were prepared as triplicates and a mean was calculated for each. To measure the cell viability as a percentage, the absorbance value of each sample was divided by the absorbance value for the control (media only), and multiplied by 100.

\subsection{Protein Corona Analysis Using Liquid Chromatography and Mass Spectrometry (LC/MS)}

$20 \mu \mathrm{L}$ of $1 \mathrm{M}$ of $\mathrm{MgCl}_{2}$ was added to $10 \mu \mathrm{L}$ of $1 \mathrm{M} \mathrm{NaF}$ and incubated at $37^{\circ} \mathrm{C}$ for $30 \mathrm{~min}$. DMEM media supplemented with $10 \%$ FBS. The final volume the sample was $1 \mathrm{~mL}$. The sample was then incubated again at $37^{\circ} \mathrm{C}$ for $30 \mathrm{~min}$ then centrifuged at $13,000 \mathrm{rpm}$ and $20^{\circ} \mathrm{C}$ for $10 \mathrm{~min} .970 \mu \mathrm{L}$ of the supernatant was then removed and replaced with $970 \mu \mathrm{L}$ water, without mixing with the precipitate. The sample was centrifuged a second time under the same settings, and $970 \mu \mathrm{L}$ of supernatant was discarded. The precipitate was resuspended in $100 \mu \mathrm{L}$ of $50 \mathrm{mM}$ EDTA.

To perform liquid chromatography, a C18 spin column (ThermoScientific) was used. The column was centrifuged at $1500 \mathrm{rcf}$ for $1 \mathrm{~min}$ after each solution was added in order for it to flow through. Each step mentioned below was repeated twice. $200 \mu \mathrm{L}$ of Activation solution (50\% methanol) was used to rinse the column and wet the resin. This was followed up by running $200 \mu \mathrm{L}$ of Equilibration solution ( $0.5 \%$ trifluoroacetic acid in $5 \%$ acetonitrile) through the column. The nanoparticle sample was mixed with ${ }^{1} / 3$ Sample Buffer ( $2 \%$ trifluoroacetic acid in $20 \%$ acetonitrile) and the total volume was made out to be $120 \mu \mathrm{L}$. The sample was run through the column, and the collected flow through was reintroduced into the column to maximise sample loading onto the resin. Next, $200 \mu \mathrm{L}$ of Wash solution (same composition as Equilibration solution) was run through the column. $20 \mu \mathrm{L}$ of Elution buffer ( $70 \%$ acetonitrile) was run, and the collected flow through ( $40 \mu \mathrm{L}$ for each sample) was dried in a vacuum evaporator (Eyela centrifugal evaporator) overnight. 


\section{In-Solution Digestion}

The pellet formed from the evaporated sample was resuspended in $100 \mu \mathrm{L} .50 \mu \mathrm{L}$ was drawn out for further experimentation. It was added to $25 \mu \mathrm{L}$ ammonium bicarbonate, $25 \mu \mathrm{L}$ TFE (trifluoroethanol), and $1 \mu \mathrm{L}$ of DTT (dithiothreitol). The sample was then incubated at $60{ }^{\circ} \mathrm{C}$ for $60 \mathrm{~min}$. After that, $4 \mu \mathrm{L}$ of IAM (iodoacetamide) was added and the sample incubated at room temperature under light sensitive conditions for $60 \mathrm{~min}$. Next, $300 \mu \mathrm{L}$ of water, $100 \mu \mathrm{L}$ ammonium bicarbonate and $10 \mu \mathrm{L}$ trypsin were added and the solution was incubated at $37^{\circ} \mathrm{C}$ overnight. $1 \mu \mathrm{L}$ of formic acid was then added and the sample was put in an incubator for $24 \mathrm{~h}$.

The sample was subjected to mass spectroscopy and the result was analysed by protein identification through automated de novo sequencing using PEAKS software.

\subsection{Statistical Analyses}

Error bars on all the charts represent the standard deviation, which was calculated using the standard deviation formula:

$$
\text { Error bars }=\sqrt{ } \frac{\Sigma(x-\bar{x})^{2}}{n}
$$

GraphPad software (San Diego, CA, USA) was used to calculate $p$ values for the particle cytotoxicity and cell viability results of drug (control) and particle-bound drug samples. A $t$-test was applied to compare each nanoparticle formulation's toxicity with the control. $t$-tests were also applied to each individual nanoparticle-bound doxorubicin concentration vs the control. GraphPad software was also used to calculate the confidence interval of cytotoxicity of particle-bound drugs.

\section{Results}

\subsection{Fabrication and Characterization of Nanocrystals}

Fabrication of nanocrystals was assessed using absorbance measurements as an indication of nanoparticle formation. As shown in Figure 2, overall increase in absorbance values was observed with increasing $\mathrm{NaF}$ concentrations. Absorbance values were higher at $10 \mathrm{mM}$ up to $30 \mathrm{mM}$ and reduced at $40 \mathrm{mM}$. This dip at $40 \mathrm{mM}$ was a persistent pattern observed across all repetitions of the experiment and may be accounted for by other factors unrelated to the actual absorption. This is addressed in the discussion section. Increasing the incubation time to $60 \mathrm{~min}$ resulted overall in an increase in absorbance values, as Figure 3 shows. Regarding the $50 \mathrm{mM}$ point in Figure 3, that is likely an anomaly. The two values for $30 \mathrm{~min}$ and $60 \mathrm{~min}$ are close enough, and it seemed that incubation stops having an effect at $40 \mathrm{mM}$ point probably due to the environment being saturated with $\mathrm{NaF}$.

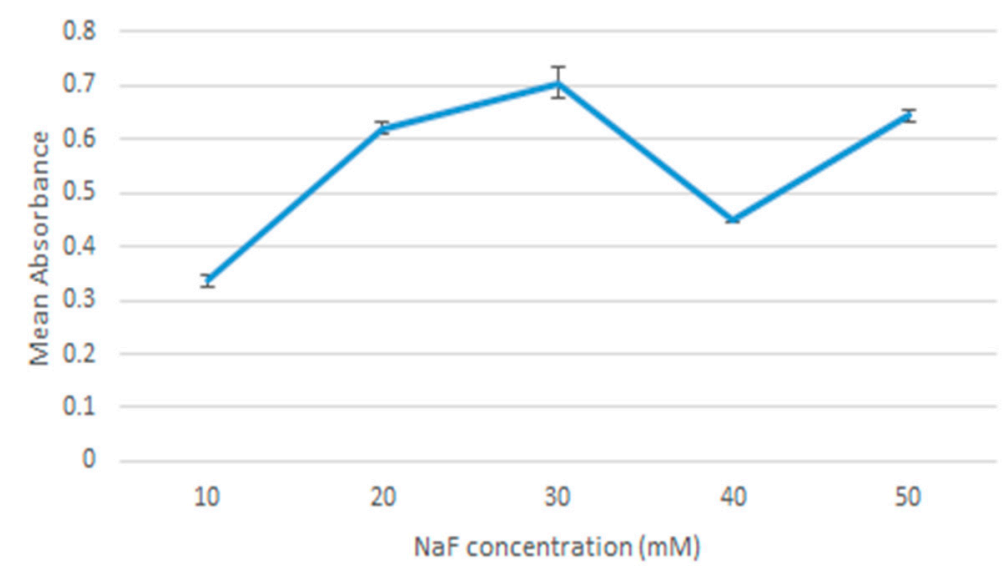

Figure 2. Absorbance values of $\mathrm{MgF}_{2}$ measured against $10 \mu \mathrm{L}$ increments of $\mathrm{NaF}$. 


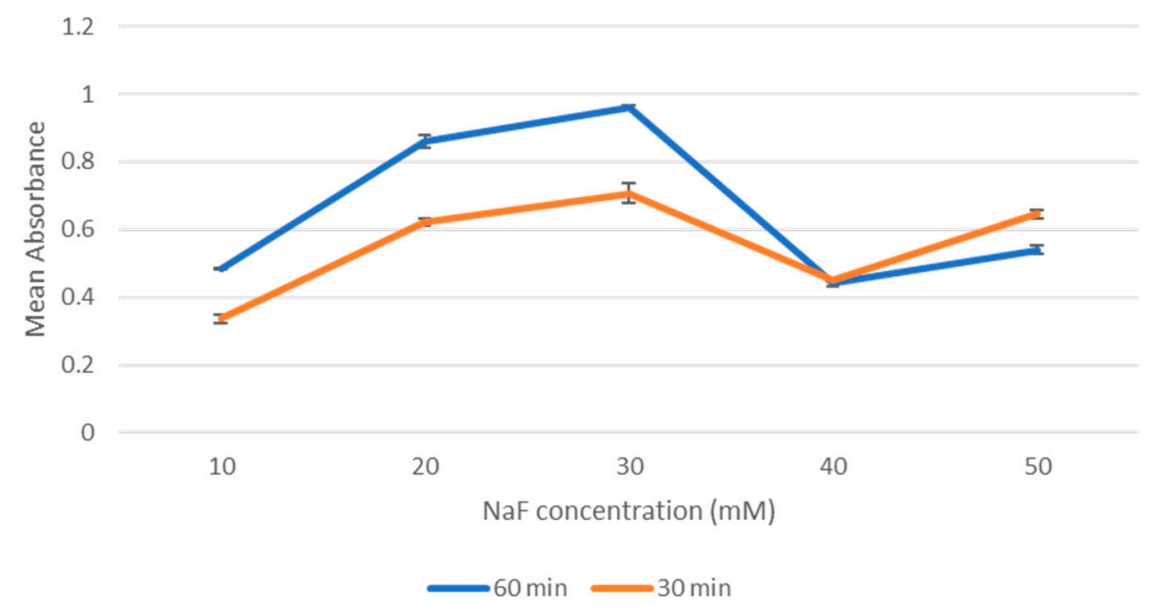

Figure 3. The effect of incubation time on absorbance values.

\subsection{Dynamic Light Scattering (DLS)}

Dynamic light scattering was used to measure the size of the particles formed (Figure 4). The dip at $40 \mathrm{mM}$ is consistent with the spectrophotometry pattern, and is addressed in the discussion.

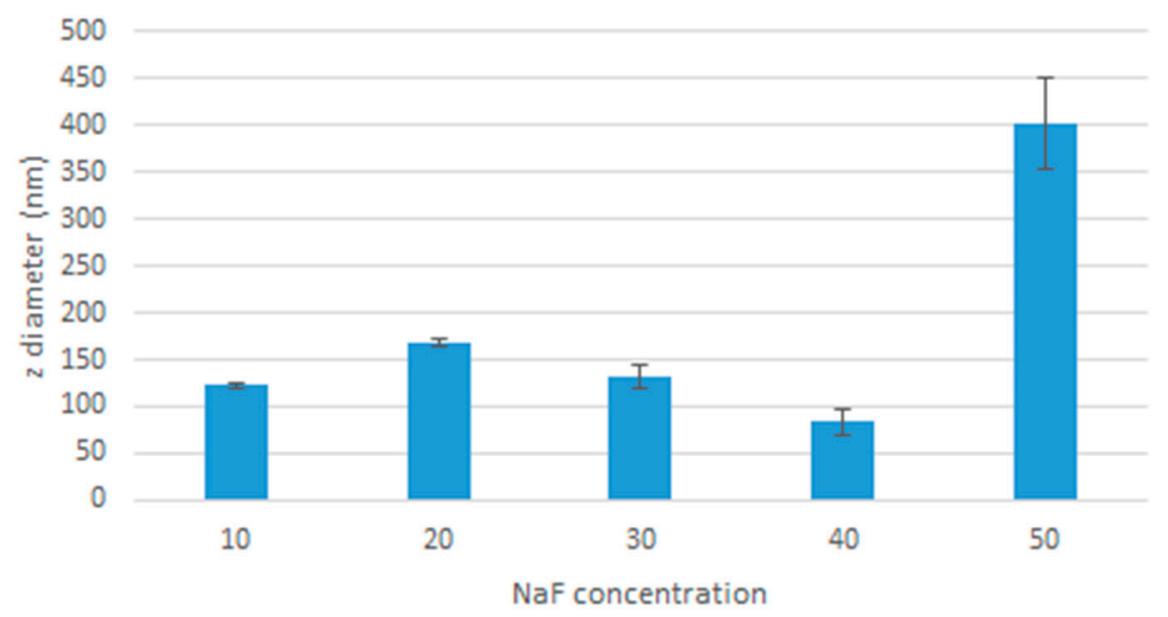

Figure 4. Effect of increased $\mathrm{NaF}$ concentration on the average diameter of $\mathrm{MgF}_{2}$ particles.

The two graphs in Figure 5 below give additional details on the distribution of the particles in a suspension of $20 \mathrm{mM}$ of $\mathrm{MgCl}_{2}$ and $10 \mathrm{mM}$ of $\mathrm{NaF}$. The average size here was $122 \mathrm{~nm}$. The polydispersity index (PDI) of the nanoparticles was 1 . This value suggests a great diversity in the sizes of the particles formed. The top-most graph displays the distribution of particles by percentage. Most of the particles (in terms of sheer numbers) fall within an average of $9 \mathrm{~nm}$ diameter, with a smaller percentage within $32 \mathrm{~nm}$ average and $190 \mathrm{~nm}$ average. This is consistent with the diversity observed in SEM images (Figure 8). In terms of intensity, most of the light scattering was observed for particles within $190 \mathrm{~nm}$ diameter, followed by $1345 \mathrm{~nm}$ particles and $39 \mathrm{~nm}$. 
(a)

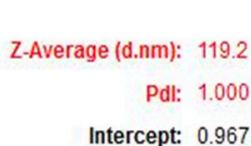

$\begin{array}{ll} & \text { Size (d.nm): } \\ \text { Peak 1: } & 8.949 \\ \text { Peak 2: } & 32.22 \\ \text { Peak 3: } & 108.0\end{array}$

$\%$ Number:

97.5

2.4

0.1
St Dev (d.nm):

2.089

10.75

36.79

Result quality : Refer to quality report

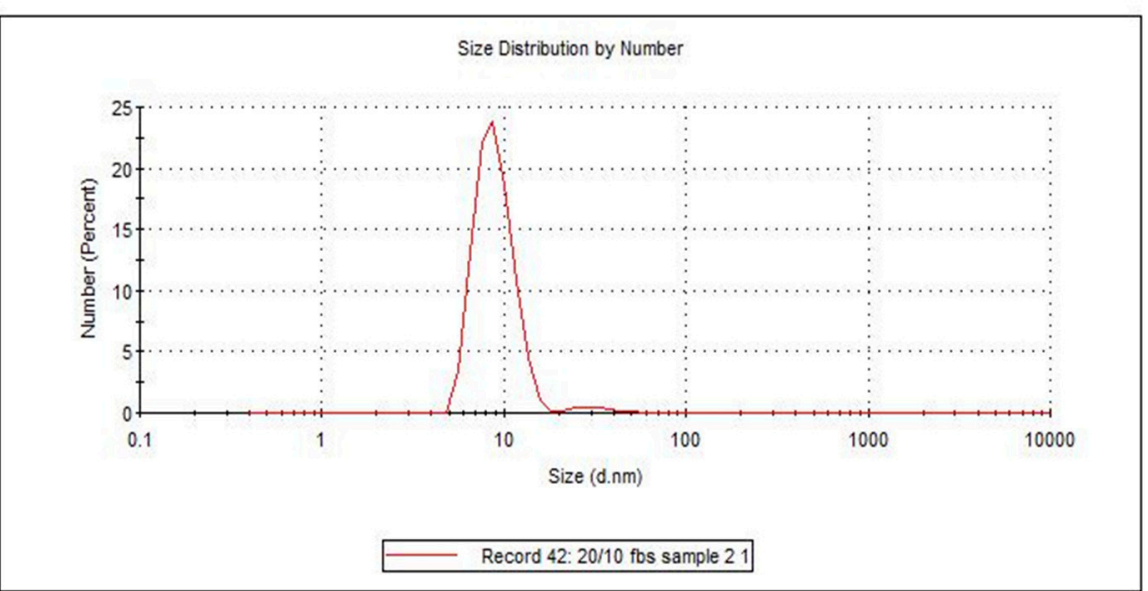

(b)

\begin{tabular}{rlllll} 
& & Size (d.nm): & \% Intensity: & St Dev (d.nm): \\
Z-Average (d.nm): 119.2 & Peak 1: & 190.7 & 43.9 & 95.56 \\
Pdl: 1.000 & Peak 2: & 1345 & 35.1 & 729.0 \\
Intercept: 0.967 & Peak 3: & 38.64 & 9.6 & 10.67 \\
Result quality : & Refer to quality report & & & \\
\hline
\end{tabular}

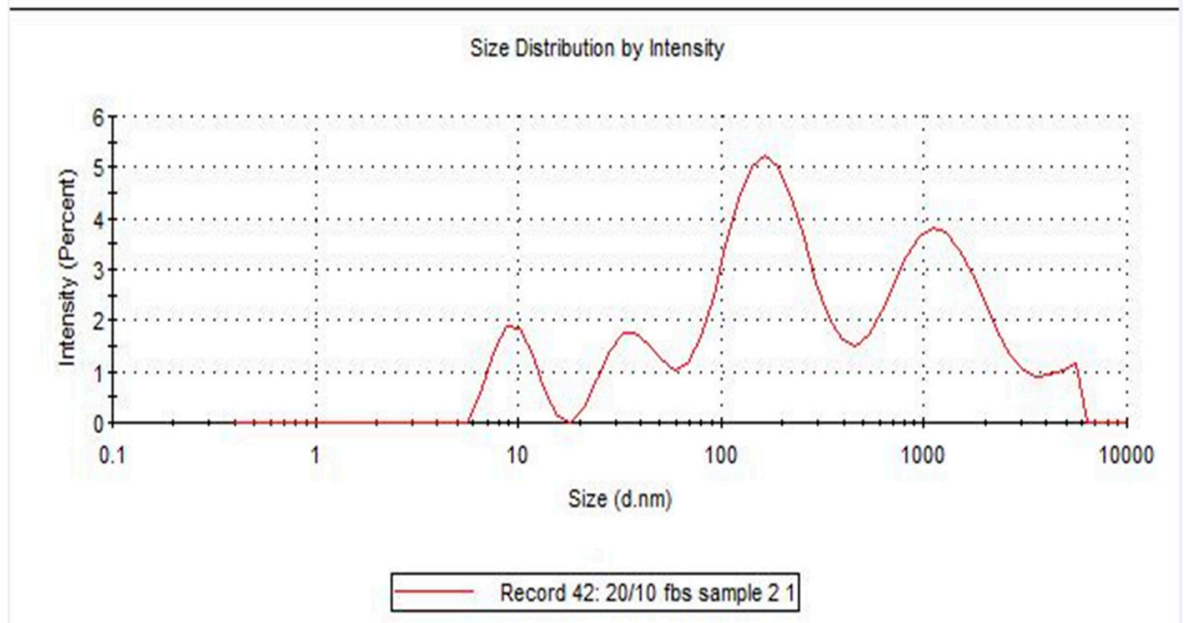

Figure 5. Size distribution of $\mathrm{MgF}_{2}$ particles in a suspension of $20 \mathrm{mM}$ of $\mathrm{MgCl}_{2}$ and $10 \mathrm{mM}$ of $\mathrm{NaF}$ in terms of a) \% numbers b) \% intensity.

\subsection{Microscopic Observation of the Particles}

Particles were viewed (Figure 6) under a brightfield $10 \times$ microscope to visualise the pattern of particle growth as the concentration of $\mathrm{NaF}$ used in formulating the particles was increased. There was a trend for particle size to increase with $\mathrm{NaF}$ concentrations $10-30 \mathrm{mM}$, then drop at $40 \mathrm{mM}$, but pick up again at $50 \mathrm{mM}$. This pattern at $40 \mathrm{mM}$ is consistent with the absorbance and dynamic light scattering observations. 


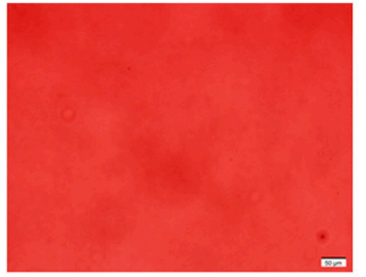

Media only

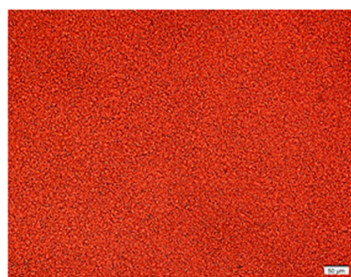

- $20 \mathrm{mM} \mathrm{MgCl}_{2}+30 \mathrm{mM} \mathrm{NaF}$

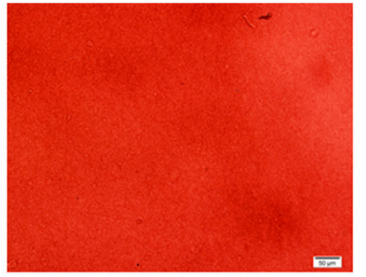

- $20 \mathrm{mM} \mathrm{MgCl}_{2}+10 \mathrm{mM} \mathrm{NaF}$

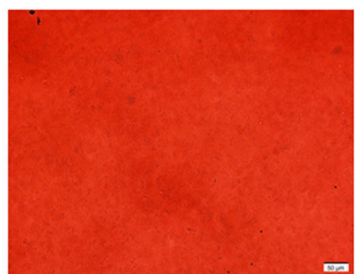

- $20 \mathrm{mM} \mathrm{MgCl}_{2}+40 \mathrm{mM} \mathrm{NaF}$

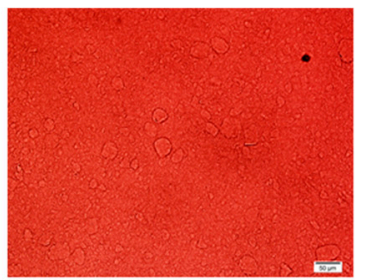

- $20 \mathrm{mM} \mathrm{MgCl}_{2}+20 \mathrm{mM} \mathrm{NaF}$

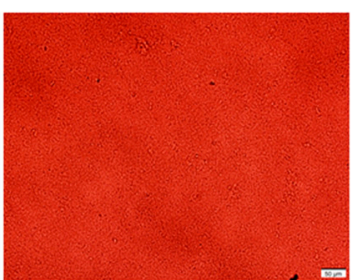

- $20 \mathrm{mM} \mathrm{MgCl}+50 \mathrm{mM} \mathrm{NaF}$

Figure 6. Microscopic images of the $\mathrm{MgF}_{2}$ suspensions.

\subsection{FTIR}

FTIR was performed to look at the chemical bonds formed within the nanoparticles. Figure 7 displays the spectrum detected. An O-H peak was observed at $3342 \mathrm{~cm}^{-1}$. Peaks at 1639, 1548 and $1443 \mathrm{~cm}^{-1}$ suggest carbonate group from DMEM. The peak at $589 \mathrm{~cm}^{-1}$ corresponds to $\mathrm{Mg}-\mathrm{F}$ (indexed as $601 \mathrm{~cm}^{-1}$ ). No peak was observed corresponding to $\mathrm{Mg}-\mathrm{Cl}$ (indexed as $721 \mathrm{~cm}^{-1}$ ) or Na-F (indexed as $\left.599 \mathrm{~cm}^{-1}\right)$, although it may have overlapped with $\mathrm{Mg}-\mathrm{F}$ absorbance.

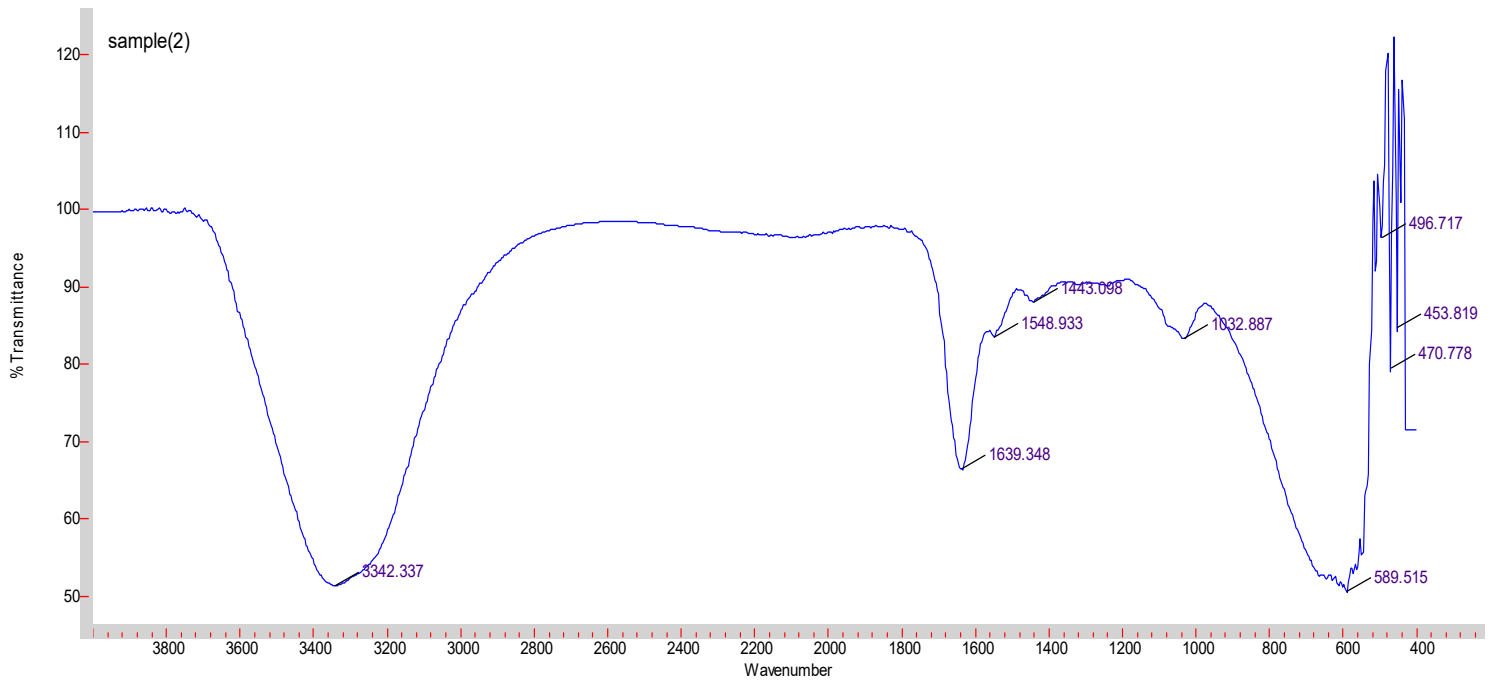

Figure 7. FTIR spectrum graph for $\mathrm{MgF}_{2}$.

\subsection{FE-SEM and EDX}

As shown in Figure 8, the particles formed were of a cubic shape. Their sizes ranged from $200 \mathrm{~nm}$ to $600 \mathrm{~nm}$ and $1 \mu \mathrm{m}$. As the images suggest, the majority of particles $<200 \mathrm{~nm}$, which is consistent with the dynamic light scattering size distribution graphs (Figure 5). The variety of particle sizes is consistent with the high polydispersity value of ' 1 ' reported with dynamic light scattering data. Figure 9 shows EDX measured at two points on an SEM image. EDX analysis showed presence of $\mathrm{Mg}$, $\mathrm{F}, \mathrm{Na}$, and $\mathrm{Cl}$ on the crystals. 

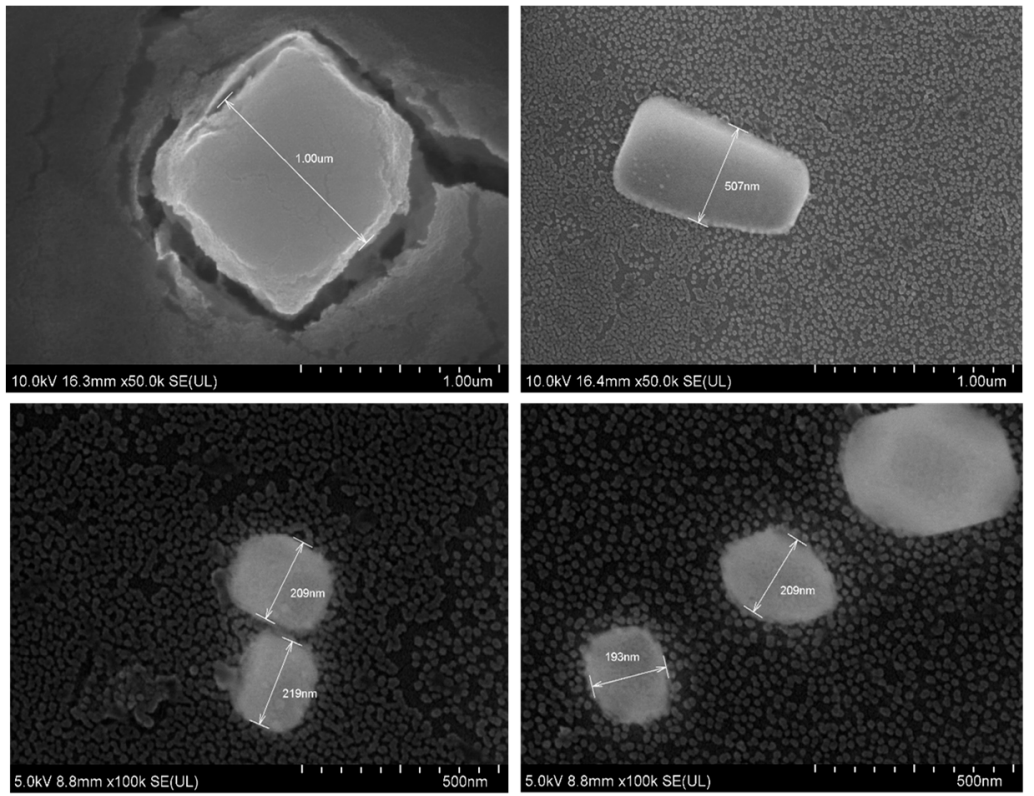

Figure 8. SEM images of $\mathrm{MgF}_{2}$.
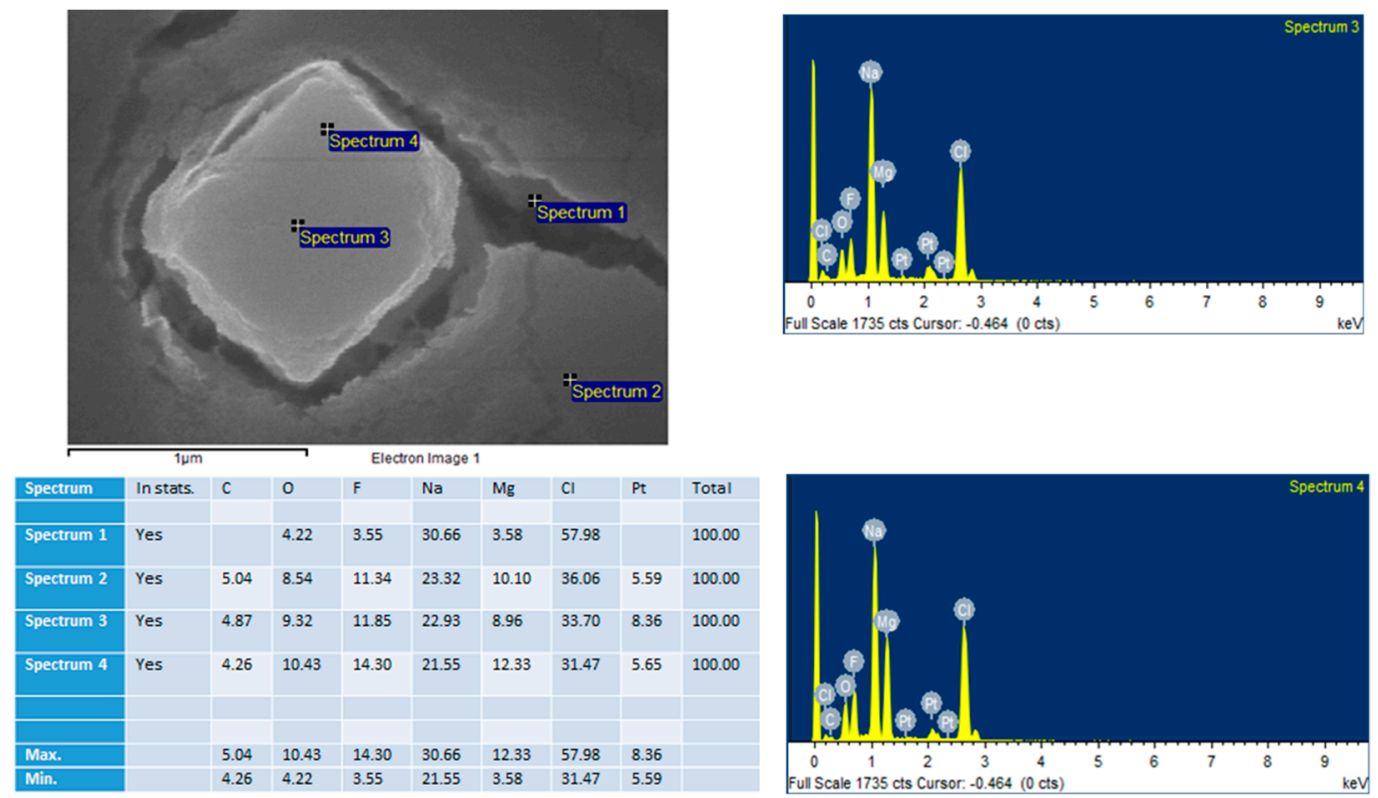

Figure 9. An SEM image of $\mathrm{MgF}_{2}$ with EDX measured at two points on the image: 'Spectrum 3' and 'Spectrum 4 '.

\section{6. $p H$ Sensitivity of the Nanoparticles}

$\mathrm{pH}$ sensitivity of the particles was assessed through photometric absorbance of particles formulation in media of different $\mathrm{pH}$. As Figure 10 shows, reducing the $\mathrm{pH}$ led to a decrease in absorbance values, indicating breakdown of the nanoparticles. The graph shows a steep decline in absorbance going from 0.4584 (at pH 7.5) down to 0.0904 (at pH 7.0), implying that most of the particles dissolved as you went down from 7.5 to 7.0. The particles were all dissolved by $\mathrm{pH}$ 5.5. 


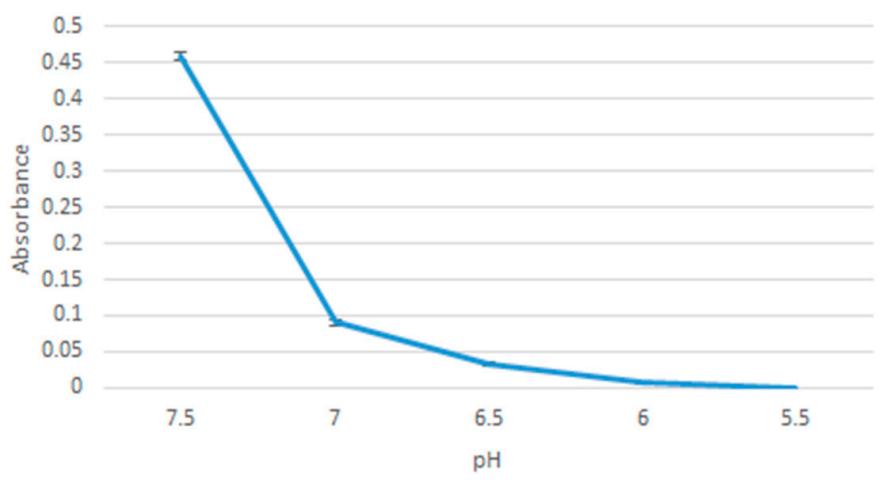

Figure 10. Absorbance of $\mathrm{MgF}_{2}$ measured against decreasing $\mathrm{pH}$ values.

\subsection{Drug Binding Affinity of Particles to Doxorubicin}

As Figure 11 shows, binding affinity seems to be consistent for the different concentrations of doxorubicin, with minor differences detected. At $5 \mu \mathrm{M}$, the binding affinity was $13.5 \% \pm 3.45$ standard deviations, which places it within the vicinity of the binding affinity at $20 \mu \mathrm{M}$, which was $10.7 \% \pm 1.8$ standard deviations.

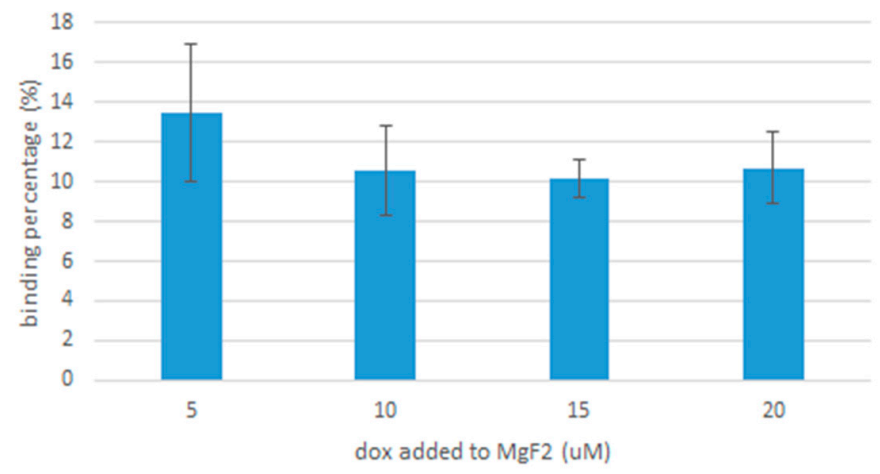

Figure 11. The binding affinity of different concentrations of doxorubicin bound to $\mathrm{MgF}_{2}$.

\section{8. $p H$ Release Profile of Doxorubicin}

Decrease in fluorescence intensity of doxorubicin in $\mathrm{MgF}_{2}$-bound formulations as you reduce media $\mathrm{pH}$ from 7.5 to 5.0 was used to estimate the amount of doxorubicin released from the nanoparticles. Figure 12 shows that there was a general pattern of more doxorubicin being released as $\mathrm{pH}$ decreased, in line with the results observed with $\mathrm{pH}$ sensitivity of the nanoparticles. A gradual increase was observed from 7.5 to 6.0. The highest release percentage was observed at $\mathrm{pH}$ of 5 , where $83 \%$ of doxorubicin was released.

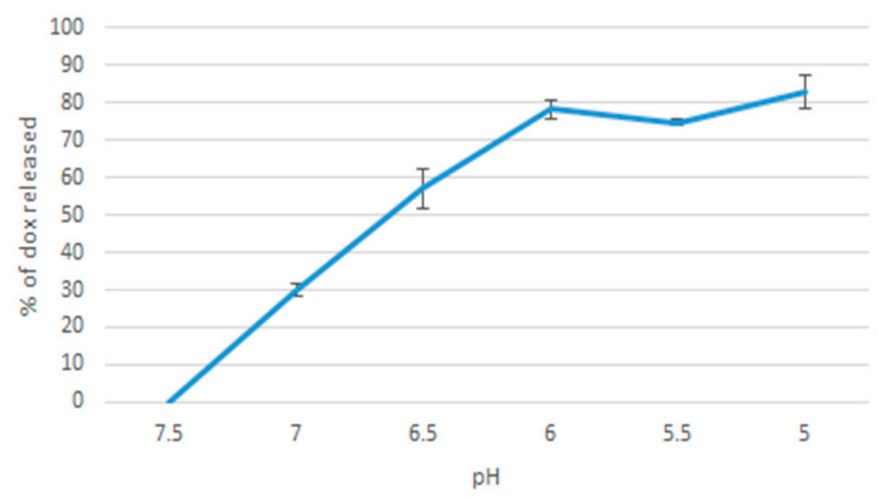

Figure 12. \% doxorubicin released as $\mathrm{pH}$ was decreased. 


\subsection{Cellular Uptake of Doxorubicin-Bound Nanoparticles}

To assess the cellular uptake of $\mathrm{MgF}_{2}$-bound doxorubicin, MCF-7 cells were treated with $10 \mu \mathrm{M}$ particle-bound doxorubicin and $10 \mu \mathrm{M}$ free doxorubicin as a control. Media was removed and the wells were rinsed with PBS, before examination under a fluorescence microscope. Fluorescence was measured after two hours and was more pronounced in cells receiving particle-bound doxorubicin than the free drug alone, thereby indicating a higher uptake of $\mathrm{MgF}_{2}$-bound drug compared to free drug, as Figure 13 shows.

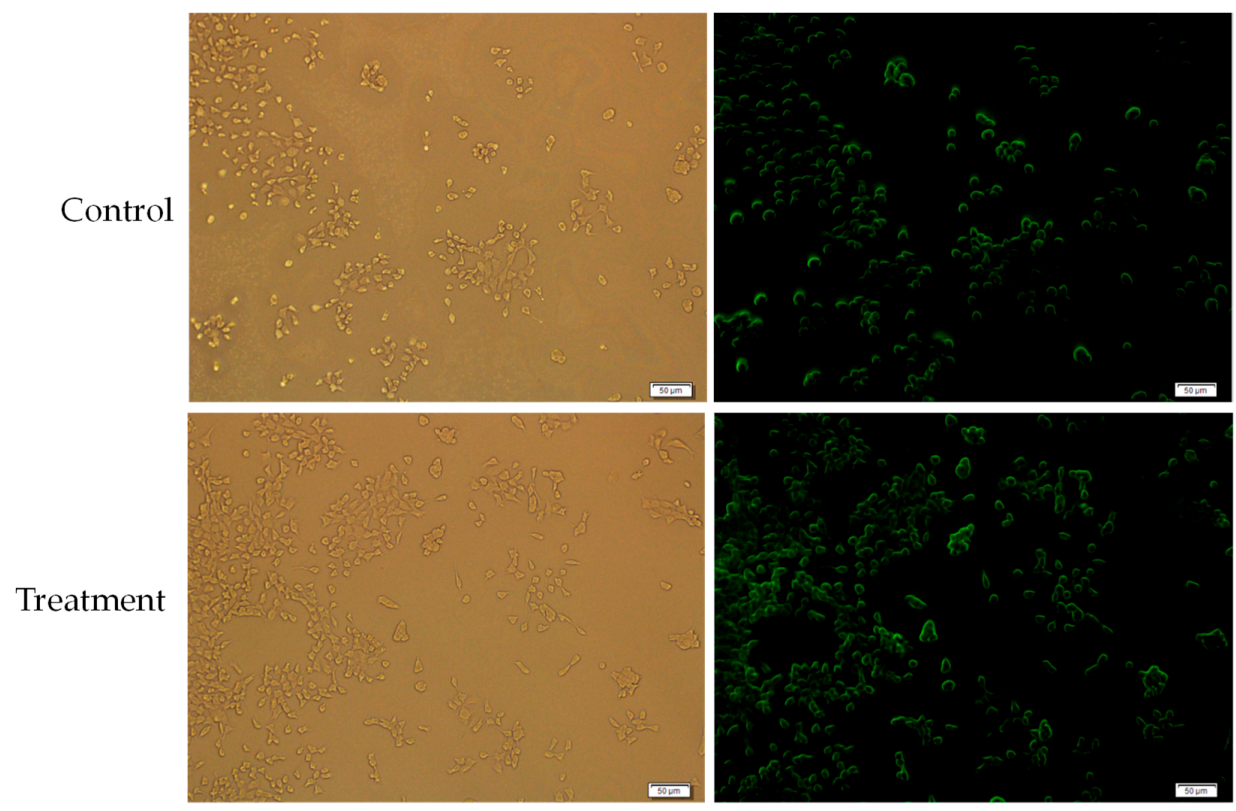

Figure 13. Cellular uptake measured after $2 \mathrm{~h}$ of control (doxorubicin as a free drug) and treatment (doxorubicin bound to $\mathrm{MgF}_{2}$ nanoparticles).

\subsection{Cytotoxicity of $M g F_{2}$ Particles}

The toxicity of $\mathrm{MgF}_{2}$ particles was assessed by calculating the percentage of cell viability for the different formulations of $\mathrm{MgF}_{2}$. These percentages were based on the results of MTT assays (see methods). As Figure 14 shows, there was an overall decrease in cell viability with increasing $\mathrm{NaF}$ concentrations. A cell viability of $80 \%(p=0.0414)$ was observed with $10 \mathrm{mM} \mathrm{NaF}$. As a result, $10 \mathrm{mM}$ of $\mathrm{NaF}$ was chosen for further experimentation. Cell viability at 20 was $24 \%(p=0.0002), 30$ was $8 \%$ $(p<0.0001), 40$ was 12\% ( $p<0.0001), 50$ was $22 \%(p<0.0001)$.

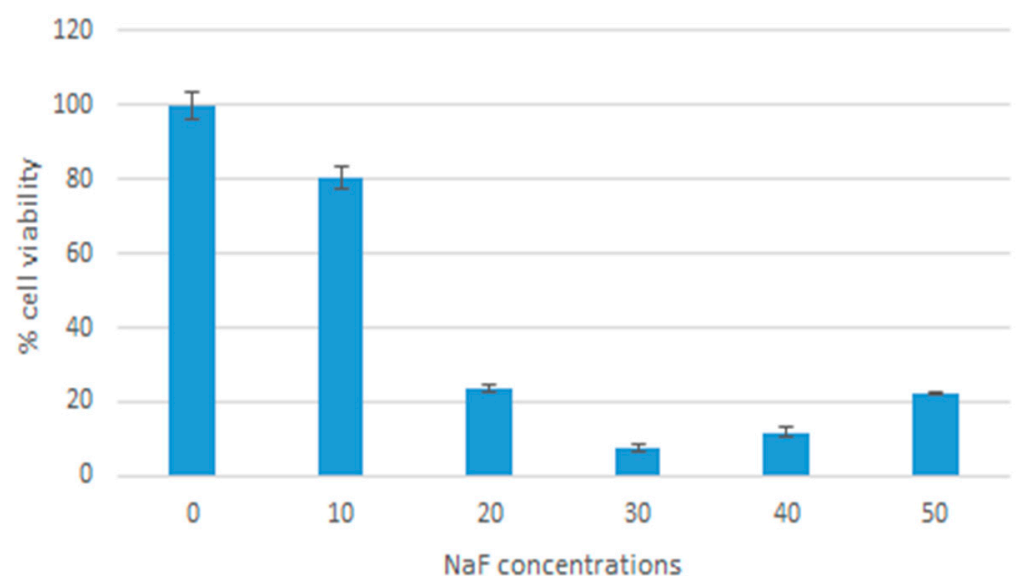

Figure 14. Cytotoxicity of $\mathrm{MgF}_{2}$ nanoparticles. 


\subsection{Toxicity of Doxorubicin-Bound $M g F_{2}$ Particles}

Toxicity of free doxorubicin was compared with $\mathrm{MgF}_{2}$-bound doxorubicin of the same concentration (a range of 100, 200, 300, 400, $500 \mathrm{nM}$ was used). Just like with nanoparticle toxicity, MTT assays were used to calculate cell viability percentages. As Figure 15 shows, cell viability decreased in both control and treatment as doxorubicin concentration increased. $\mathrm{MgF}_{2}$-bound doxorubicin had lower cell viabilities compared with free drug in most cases.

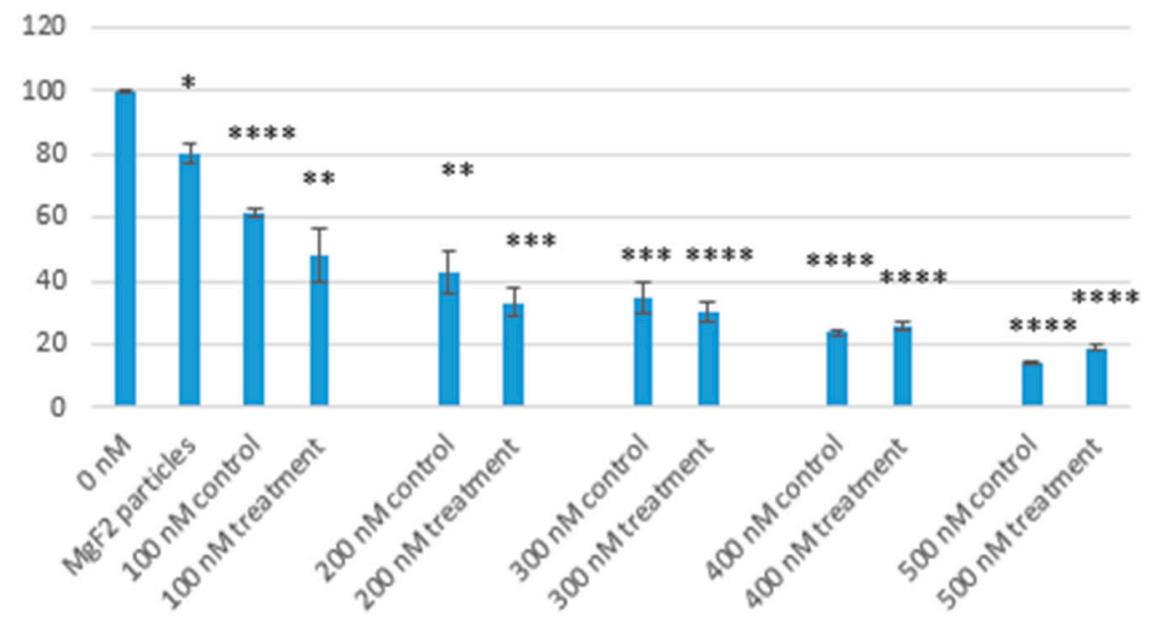

Figure 15. Comparing cell viabilities of $\mathrm{MgF}_{2}$ nanoparticle, doxorubicin-bound $\mathrm{MgF}_{2}$ particles and free drug controls. Control = drug in media; Treatment $=$ particle-bound doxorubicin, as described; ${ }^{*}=p$ value $0.05-0.01 ;{ }^{* *}=p$ value $0.01-0.001 ;{ }^{* * *}=p$ value $0.001-0.0001 ;{ }^{* * * *}=p$ value $<0.0001 ; p$ values were calculated using $0 \mathrm{nM}$ for comparison.

At $100 \mathrm{nM}$, cell viability was $61.5 \%$ ( $p<0.0001$; 95\% confidence interval (CI): $54.6-68.4)$ for control, and $48.4 \%(p=0.0044 ; 95 \%$ CI: $10.2-86.7)$ for treatment. At $200 \mathrm{nM}$, it was $43.0 \%(p=0.0012 ; 95 \% \mathrm{CI}$ : 13.1-72.8) for control, and 33.3\% ( $p=0.0001 ; 95 \%$ CI: 14.3-52.2) for treatment. At $300 \mathrm{nM}$, it was $34.8 \%$ $(p=0.0002 ; 95 \%$ CI: 14.1-55.3) for control, and 30.2\% ( $p<0.0001 ; 95 \%$ CI: 16.0-44.3) for treatment. At $400 \mathrm{nM}$, it was 23.6\% ( $p<0.0001 ; 95 \%$ CI: 19.3-28.1) for control, and $26 \%(p<0.0001 ; 95 \%$ CI: 19.2-32.8) for treatment. At $500 \mathrm{nM}$, it was $14.2 \%(p<0.0001 ; 95 \%$ CI: $10.5-17.8)$ for control, and $18.7 \%$ $(p<0.0001 ; 95 \%$ CI: 14.6-22.8) for treatment.

\subsection{Protein Corona Analysis Using Liquid Chromatography and Mass Spectrometry (LC/MS)}

Table 1 shows the constituents of the protein corona around the nanoparticle in 10\% FBS. Most of the proteins bound to $\mathrm{MgF}_{2}$ particles have an isoelectric point $<7.5$, i.e., are negatively charged in physiological $\mathrm{pH}$. They would most likely be drawn to the positive region around the $\mathrm{Mg}^{2+}$ ions in the nanoparticle structure. A few proteins, like the keratins and globins, are positive in physiological $\mathrm{pH}$ and are likely drawn to the $\mathrm{F}^{-}$ions in the nanoparticle structures. There is a great variety in the molecular weight of the proteins in the corona.

Figure 16 is a pie chart that shows the distribution of proteins in the corona by functions. As the figure showed, transport proteins made up the largest segment (57\%) of the protein corona. This included albumen proteins, which are the most abundant proteins in plasma, constituting around $55 \%$ of plasma proteins [10], and are known dysopsonins, i.e., inhibit opsonisation. Opsosnins such as globulins, complement proteins and fibrinogen were missing in the corona [11]. 
Table 1. Protein corona constituents formed around the nanoparticles in 10\% FBS-supplemented DMEM media.

\begin{tabular}{|c|c|c|c|c|c|}
\hline No. & Description & Avg. Mass & Coverage $(\%)$ & Function & Isoelectric Point (pI) \\
\hline 1 & Alpha-2-HS-glycoprotein & 38,419 & 85 & acute phase protein & 5.94 \\
\hline 2 & Alpha-2-HS-glycoprotein & 38,419 & 85 & acute phase protein & 5.94 \\
\hline 3 & ALB protein & 69,294 & 73 & $\begin{array}{l}\text { transport and } \\
\text { binding protein }\end{array}$ & 5.4 \\
\hline 4 & Serum albumin & 69,324 & 72 & $\begin{array}{l}\text { transport and } \\
\text { binding protein }\end{array}$ & 5.4 \\
\hline 5 & Serum albumin & 69,294 & 72 & $\begin{array}{l}\text { transport and } \\
\text { binding protein }\end{array}$ & 5.4 \\
\hline 6 & Apolipoprotein A-I & 30,276 & 69 & lipid transport & 5.56 \\
\hline 7 & $\begin{array}{l}\text { Apolipoprotein A-I } \\
\text { preproprotein }\end{array}$ & 30,276 & 69 & lipid transport & 5.56 \\
\hline 8 & Alpha-1-antiproteinase & 46,104 & 24 & protease inhibitor & 5.4 \\
\hline 9 & Prothrombin & 70,506 & 18 & coagulation & 5.64 \\
\hline 10 & Vitronectin & 53,575 & 19 & cell adhesion & 5.55 \\
\hline 11 & Apolipoprotein A-II & 11,202 & 60 & lipid transport & 5.56 \\
\hline 12 & Hemoglobin fetal subunit beta & 15,859 & 39 & oxygen transport & 7.1 \\
\hline 13 & Keratin 1 & 63,151 & 9 & structural protein & 8.15 \\
\hline 14 & Keratin type I cytoskeletal 10 & 54,848 & 19 & structural protein & 8.15 \\
\hline 15 & Keratin 10 & 54,849 & 19 & structural protein & 8.15 \\
\hline 16 & Adiponectin & 26,133 & 20 & fat metabolism & 5.42 \\
\hline 17 & Serotransferrin & 77,753 & 14 & iron transport & 6.81 \\
\hline 18 & Serotransferrin & 77,666 & 14 & iron transport & 6.81 \\
\hline 19 & Globin C1 & 15,184 & 44 & oxygen transport & $6-8$ \\
\hline 20 & Hemoglobin subunit alpha & 15,184 & 44 & oxygen transport & 7.1 \\
\hline 21 & Antithrombin-III & 52,440 & 9 & anticoagulant & 5.93 \\
\hline 22 & Antithrombin-III & 52,347 & 9 & anticoagulant & 5.93 \\
\hline 23 & Vitamin D-binding protein & 53,356 & 7 & vitamin $\mathrm{d}$ transport & 5.2 \\
\hline 24 & Vitamin D-binding protein & 53,328 & 7 & vitamin $\mathrm{d}$ transport & 5.2 \\
\hline 25 & Vitamin D-binding protein & 53,342 & 7 & vitamin $\mathrm{d}$ transport & 5.2 \\
\hline 26 & APOM protein & 13,027 & 17 & lipid transport & 5.66 \\
\hline 27 & Apolipoprotein M & 21,158 & 11 & lipid transport & 5.66 \\
\hline 28 & $\begin{array}{l}\text { Apoptotic chromatin } \\
\text { condensation inducer } 1\end{array}$ & 150,755 & 1 & apoptosis & 6.08 \\
\hline
\end{tabular}




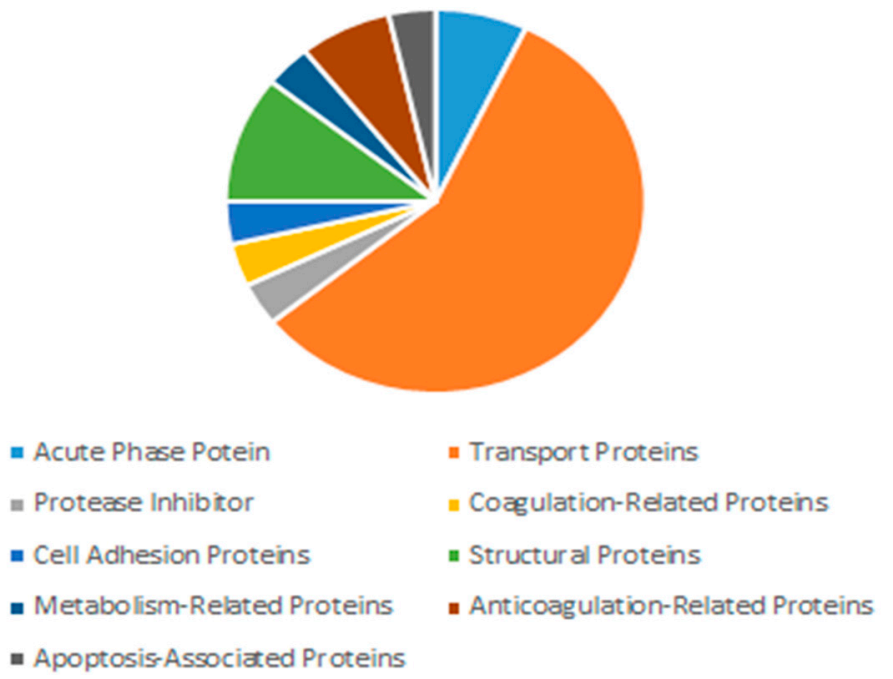

Figure 16. Distribution of proteins in the corona by function in $10 \%$ FBS.

\section{Discussion}

Drug delivery vectors can reduce the toxicity of anti-cancer drugs by targeted delivery to tumour tissue and reduction in off-target effects. Previous studies have looked into using inorganic vectors such as calcium phosphate [12], calcium carbonate [13] and magnesium silicate [14] for drug delivery. As of yet, no conclusive developments have been made in the field of inorganic nanocrystal drug carriers. Our study aimed to further our understanding of the capabilities of inorganic nanocrystals, by experimenting on magnesium fluoride. We assessed the presence (or lack of presence) of several important features, such as size, shape, composition, binding affinity, $\mathrm{pH}$-based controlled release, internalisation into cells, safety of the nanoparticles, and enhancement of the toxicity of doxorubicin.

We have demonstrated the capability of producing $\mathrm{MgF}_{2}$ nanocrystal particles by precipitating $\mathrm{MgCl}_{2}$ and $\mathrm{NaF}$. The particles formed were size-modifiable; the spectrophotometry, zeta sizer analysis and microscopic observation showed increasing size with increasing concentration of NaF. Being able to modify the size of the particles is crucial to drug delivery, as size is a major determinant in clearance from the body, uptake into tumour tissue (by enhanced permeation and retention effect (EPR), where particles are small enough to pass through leaky tumour vessels but too large to leak out of regular vessels) and internalisation into cancer cells. There is no consensus on the ideal size of nanoparticles, but close estimates have been made in the range of $10 \mathrm{~nm}$ to $200 \mathrm{~nm}$ [15]. Particles that are too small ( $8 \mathrm{~nm}$ or less) could be cleared by the kidney [16], whereas larger particles, from $200 \mathrm{~nm}$ up to $10 \mu \mathrm{m}$ are more likely to be cleared by the reticuloendothelial system and less likely to be taken up by cells $[15,17,18]$.

There was an observed decrease in absorbance, z-average diameter, and microscope observation when particles were formed using $40 \mu \mathrm{L}$ of NaF. This observation was consistent in all the experiments and the cause of it is unknown. An experiment like this has not been done before, so there lacks any data or plausible explanation for this peculiarity. As a result of these investigations, we decided to use the $20 \mu \mathrm{L}$ of $1 \mathrm{M} \mathrm{MgCl}_{2}$ and $10 \mu \mathrm{L}$ of $1 \mathrm{M} \mathrm{NaF}$ formulation for the remaining research, as it had the lowest value using the lowest concentrations, and was less likely to aggregate.

FTIR was used to determine the composition of the particles. Predictable peaks were observed corresponding to carbonate, $\mathrm{O}-\mathrm{H}$ and $\mathrm{Mg}$-F bonds. The measuring device was less capable of detecting specific absorbance peaks for the ionic bonds in the salts.

EDX analysis was another test of composition (performed live with SEM). It did show traces of $\mathrm{Na}$ and $\mathrm{Cl}_{2}$ in the crystals, displaying a variety in the composition of the crystals. This lack of 'purity' is to be expected in a simple precipitation method. 
SEM was used to assess the shape and diameter of the particles formed using $20 \mu \mathrm{L}$ of $1 \mathrm{M}$ $\mathrm{MgCl}_{2}$ and $10 \mu \mathrm{L}$ of $1 \mathrm{M} \mathrm{NaF}$. SEM analysis showed the shape of these crystals to be cubic in nature. What effect the shape of a particle has on its function is still not a settled topic. Work by Ye et al. suggests that non-spherical nanoparticles (such as in this case) are more resistant to sequestration by the reticuloendothelial system [19]. The diameter ranged from $200 \mathrm{~nm}-1 \mu \mathrm{m}$. Most of the particles were, however, smaller than $200 \mathrm{~nm}$ (seen in the background of the images). This is consistent with the size distribution graph (Figure 5) and the high polydispersity value reported by the zetasizer software reported for this formulation.

Drug binding to $\mathrm{MgF}_{2}$ was consistent for the different concentrations of doxorubicin we tested: 5, 10,15 and $20 \mu \mathrm{M}$. The binding affinity is comparable to that of carbonate apatite; reported by Hossain et al. as $19 \%$ for $5 \mu \mathrm{M}$ of doxorubicin [20] (our value for $5 \mu \mathrm{M}$ of doxorubicin was $13.5 \% \pm 3.45$, giving us an upper limit of $17 \%$ ). It could be improved by modifications to $\mathrm{MgF}_{2}$, e.g., conjugation with ligands.

$\mathrm{pH}$ sensitivity of the nanoparticles is important for a controlled release function. Together with a $\mathrm{pH}$ release profile of doxorubicin, we could have a picture of whether $\mathrm{MgF}_{2}$ nanoparticles can be relied upon to release doxorubicin only when in (more acidic) tumour tissues. $\mathrm{pH}$ sensitivity was observed by comparing spectrophotometric absorbance values of particles formed in media of $\mathrm{pH} 7.5,7.0,6.5$, 6.0, 5.5. $\mathrm{pH}$ sensitivity results suggest that most of the nanoparticles will have dissolved at $7.0 \mathrm{pH}$, which is within the range of $\mathrm{pH}$ in a tumour microenvironment (believed to be in the range of 6.8-7.2, although the values are not consistent throughout the tumour tissues) [21]. Further modifications may have to be made to modulate the sensitivity of $\mathrm{MgF}_{2}$ to $\mathrm{pH}$.

The experiment on $\mathrm{pH}$ associated release of doxorubicin produced a gradual curve upwards on the \% release vs $\mathrm{pH}$ graph. This is consistent with $\mathrm{pH}$ sensitivity, as you would expect more doxorubicin to be released as more particles breakdown as the $\mathrm{pH}$ decreases.

The fluorescence of cells treated with $\mathrm{MgF}_{2}$-bound doxorubicin was compared with the fluorescence of cells treated with free unbound drug (the control) to estimate if cellular uptake of doxorubicin was changed when bound to $\mathrm{MgF}_{2}$. The increased fluorescence of cells treated with $\mathrm{MgF}_{2}$-bound doxorubicin indicated that $\mathrm{MgF}_{2}$-bound doxorubicin was more readily taken up into cancer cells than the free drug. Cellular uptake depends on various factors like particle charge and hydrophilicity/hydrophobicity [22], but size is the most important one [15]. Particles in the range of 60-200 $\mathrm{nm}$ in size can be taken up through the clathrin pathway. Particles of $200 \mathrm{~nm}-1 \mathrm{uM}$ can be taken up through the caveolae pathway [22]. Considering the size of the $\mathrm{MgF}_{2}$ particles, they would most likely have been taken up by the clathrin-mediated pathway.

MTT analysis showed low cytotoxicity of nanoparticles in low concentrations. When using $10 \mu \mathrm{L}$ of $\mathrm{NaF}$, the particles formed reduced cell viability by $20 \%$ when compared to media alone. Our findings are consistent with other studies on magnesium-based nanoparticles, which reported low levels of toxicity [23-25]. MTT analysis was also used to determine the effect of $\mathrm{MgF}_{2}$ binding on the toxicity of doxorubicin. We observed enhanced toxicity of doxorubicin when bound to $\mathrm{MgF}_{2}$ particles. Optimum reduction in cell viability was observed at $400 \mathrm{nM}$ concentration of doxorubicin, where we brought down cell survival to under $30 \%$. The enhanced toxicity of doxorubicin can be attributed to enhanced cellular uptake, as observed in the previous experiment.

A protein corona forms naturally around any object inserted into plasma/serum, and generally comprises protein constituents of the bodily fluid. The types of proteins that attach to a nanoparticle depend on its size, charge and solubility. Protein corona formation can affect the size of the particles, its clearance by the reticuloendothelial system and its cellular uptake.

The most abundant proteins in the serum/plasma are albumin proteins, followed by immunoglobulins and coagulation proteins. The constituents of the protein corona, shown in Figure 16 and Table 1, display an abundance of transport proteins, including several albumin proteins, but a lack of immunoglobulins. Some coagulation factors and acute phase reactants are present, which may contribute to opsonisation. 
Opsonisation is the process of 'tagging' foreign bodies with opsonins to facilitate clearance by the reticuloendothelial system. Opsonins are mostly immunoglobulins, complement proteins and fibrinogen. On the other hand, there are molecules in the plasma which protect foreign molecules from clearance by the reticuloendothelial system. These include albumins and apolipoproteins, both of which were observed in our nanoparticle protein corona.

In conclusion, the nanoparticles we fabricated in 10\% FBS-supplemented DMEM formed a unique protein corona consisting mainly of transport proteins with lack of presence of common opsonins. This suggests that these nanoparticles will be less likely to be cleared out by the reticuloendothelial system and thus would have an increased half-life in plasma. Limitations concerning protein corona would relate to its effect on increasing the particle size, which would undermine the EPR effect crucial for accumulation of the particles in target tissues $[11,26]$.

In summary, the benchwork and in vitro experiments displayed a potential for $\mathrm{MgF}_{2}$ particles to be used as a drug delivery system. Modifications to the nanocrystals will be needed to improve drug binding affinity and cellular uptake. The efficacy of the particles in vivo is yet to be assessed, as is the capability of surface modification with ligands to improve specific targeting and avoid sequestration in the liver and reticuloendothelial systems.

\section{Conclusions}

Off-target side effects of anti-cancer drugs increase comorbidity of breast cancer patients and overall healthcare cost. These issues could be addressed by targeted delivery using drug delivery systems. In this study we looked into the possibility of using inorganic $\mathrm{MgF}_{2}$ nanocrystal particles as a drug delivery vector. The fabrication of nanoparticles was simple and non-toxic at $10 \mathrm{mM}$ concentration. The particles were size-modifiable and capable of binding doxorubicin and internalising into cells. We demonstrated their sensitivity to $\mathrm{pH}$ and were thus capable to control their release of the drug by reducing the $\mathrm{pH}$. The particle-bound doxorubicin formulation enhanced the effect of doxorubicin in killing cancer cells.

Author Contributions: H.A.-B. carried out experiments, M.E.K. and K.K.T. provided the technical assistance and resources, S.A.Z.A. helped in LC-MS analysis, and E.H.C. designed and supervise the project.

Funding: This work has been supported by a seed grant from Health \& Wellbeing Cluster, Global Asia in the 21st Century (GA21) Platform, Monash University Malaysia.

Conflicts of Interest: The authors declare no conflicts of interest.

\section{References}

1. Barron, J.J.; Quimbo, R.; Nikam, P.T.; Amonkar, M.M. Assessing the economic burden of breast cancer in a US managed care population. Breast Cancer Res. Treat. 2008, 109, 367-377. [CrossRef] [PubMed]

2. Hassett, M.J.; O'Malley, A.J.; Pakes, J.R.; Newhouse, J.P.; Earle, C.C. Frequency and cost of chemotherapy-related serious adverse effects in a population sample of women with breast cancer. J. Natl. Cancer Inst. 2006, 98, 1108-1117. [CrossRef] [PubMed]

3. Zhao, J.; Lee, P.; Wallace, M.J.; Melancon, M.P. Gold Nanoparticles in Cancer Therapy: Efficacy, Biodistribution, and Toxicity. Curr. Pharm. Des. 2015, 21, 4240-4251. [CrossRef] [PubMed]

4. Ong, C.; Lim, J.Z.; Ng, C.T.; Li, J.J.; Yung, L.Y. Bay BH. Silver nanoparticles in cancer: Therapeutic efficacy and toxicity. Curr. Med. Chem. 2013, 20, 772-781. [PubMed]

5. Gu, X.-N.; Zheng, Y.-F. A review on magnesium alloys as biodegradable materials. Front. Mater. Sci. China 2010, 4, 111-115. [CrossRef]

6. Fornari, F.A.; Randolph, J.K.; Yalowich, J.C.; Ritke, M.K.; Gewirtz, D.A. Interference by doxorubicin with DNA unwinding in MCF-7 breast tumor cells. Mol. Pharmacol. 1994, 45, 649-656. [PubMed]

7. Thorn, C.; Oshiro, C.; Marsh, S.; Hernandez-Boussard, T.; McLeod, H.; Klein, T.; Altman, R. Doxorubicin pathways: Pharmacodynamics and adverse effects. Pharmacogenet. Genom. 2011, 21, 440-446. [CrossRef] [PubMed] 
8. Rivankar, S. An overview of doxorubicin formulations in cancer therapy. J. Cancer Res. Ther. 2014, 10, 853. [CrossRef]

9. Prados, J.; Melguizo, C.; Ortiz, R.; Vélez, C.; Alvarez, P.J.; Arias, J.L.; Ruíz, M.A.; Gallardo, V.; Aranega, A. Doxorubicin-Loaded Nanoparticles: New Advances in Breast Cancer Therapy. Anti-Cancer Agents Med. Chem. 2012, 12, 1058-1070. [CrossRef]

10. Rockland-inc.com. Available online: http://rockland-inc.com/Serum-Protein-Components.aspx (accessed on 24 November 2018).

11. Mozar, F.; Chowdhury, E. PEGylation of Carbonate Apatite Nanoparticles Prevents Opsonin Binding and Enhances Tumor Accumulation of Gemcitabine. J. Pharm. Sci. 2018, 107, 2497-2508. [CrossRef]

12. Thomas, S.C.; Harshita Mishra, P.K.; Talegaonkar, S. Ceramic Nanoparticles: Fabrication Methods and Applications in Drug Delivery. Curr. Pharm. Des. 2015, 21, 6165-6188. [CrossRef] [PubMed]

13. Maleki Dizaj, S.; Barzegar-Jalali, M.; Zarrintan, M.H.; Adibkia, K.; Lotfipour, F. Calcium carbonate nanoparticles as cancer drug delivery system. Expert Opin. Drug Del. 2015, 12, 1649-1660. [CrossRef] [PubMed]

14. Wang, B.; Meng, W.; Bi, M.; Ni, Y.; Cai, Q.; Wang, J. Uniform magnesium silicate hollow spheres as high drug-loading nanocarriers for cancer therapy with low systemic toxicity. Dalton Trans. (Camb., Engl.: 2003) 2013, 42, 8918-8925. [CrossRef] [PubMed]

15. Ahmadzada, T.; Reid, G.; McKenzie, D.R. Fundamentals of siRNA and miRNA therapeutics and a review of targeted nanoparticle delivery systems in breast cancer. Biophys. Rev. 2018, 10, 69-86. [CrossRef] [PubMed]

16. Guyton, A.C. Textbook of Medical Physiology, 11th ed.; Hall, J.E., Ed.; W.B. Saunders: Philadelphia, PA, USA, 2006.

17. Salatin, S.; Maleki Dizaj, S.; Yari Khosroushahi, A. Effect of the surface modification, size, and shape on cellular uptake of nanoparticles. Cell Biol. Int. 2015, 39, 881-890. [CrossRef] [PubMed]

18. Ding, H.M.; Ma, Y.Q. Theoretical and computational investigations of nanoparticle-biomembrane interactions in cellular delivery. Small 2015, 11, 1055-1071. [CrossRef] [PubMed]

19. Ye, H.; Shen, Z.; Yu, L.; Wei, M.; Li, Y. Manipulating nanoparticle transport within blood flow through external forces: An exemplar of mechanics in nanomedicine. Proc. R. Soc. A-Math./Phys. Eng. Sci. 2018, 474, 20170845. [CrossRef]

20. Mehbuba Hossain, S.; Chowdhury, E.H. Citrate- and Succinate-Modified Carbonate Apatite Nanoparticles with Loaded Doxorubicin Exhibit Potent Anticancer Activity against Breast Cancer Cells. Pharmaceutics 2018, 10, 32. [CrossRef]

21. Gerweck, L.E.; Seetharaman, K. Cellular pH gradient in tumor versus normal tissue: Potential exploitation for the treatment of cancer. Cancer Res. 1996, 56, 1194-1198.

22. Chowdhury, E. Nanotherapeutics from Laboratory to Clinic, 1st ed.; CRC Press: Boca Raton, FL, USA, 2016.

23. Lellouche, J.; Friedman, A.; Lahmi, R.; Gedanken, A.; Banin, E. Antibiofilm surface functionalization of catheters by magnesium fluoride nanoparticles. Int. J. Nanomed. 2012, 7, 1175.

24. Gelli, K.; Porika, M.; Anreddy, R.N.R. Assessment of pulmonary toxicity of MgO nanoparticles in rats. Environ. Toxicol. 2015, 30, 308-314. [CrossRef] [PubMed]

25. Wong, Y.; Markham, K.; Xu, Z.P.; Chen, M.; Lu, G.Q.; Bartlett, P.F.; Cooper, H.M. Efficient delivery of siRNA to cortical neurons using layered double hydroxide nanoparticles. Biomaterials 2010, 31, 8770-8779. [CrossRef] [PubMed]

26. Oh, J.Y.; Kim, H.S.; Palanikumar, L.; Go, E.M.; Jana, B.; Park, S.A.; Kim, H.Y.; Kim, K.; Seo, J.K.; Kwak, S.K.; et al. Cloaking nanoparticles with protein corona shield for targeted drug delivery. Nat. Commun. 2018, 9, 4548. [CrossRef] [PubMed]

(C) 2019 by the authors. Licensee MDPI, Basel, Switzerland. This article is an open access article distributed under the terms and conditions of the Creative Commons Attribution (CC BY) license (http:/ / creativecommons.org/licenses/by/4.0/). 